\title{
Environmental accounting: an analysis on the transformation of environmental impacts in sustainable and socioeconomic improvement, in the Supply Center Hortifrutigranjeiro - Ceasa MA
}

\author{
Lauralice Ferreira Araujo ${ }^{1}$, Delmo Silva Mattos $^{2}$ and Maria Raimunda Chagas Sillva ${ }^{3}$
}

${ }^{1}$ Universidade CEUMA - UniCEUMA, São Luís-Maranhão, Brasil. lauralice.araujo@ceuma.br

${ }^{2}$ Universidade CEUMA - UniCEUMA, São Luís-Maranhão, Brasil. delmo.mattos@hotmail.com

${ }^{3}$ Universidade CEUMA - UniCEUMA, São Luís-Maranhão, Brasil. marirah@gmail.com

\begin{abstract}
This objective of this article is to analyze the, transformation of environmental impacts into some amount of sustainable and socioeconomic improvements within the Supply Center Hortifrutigranjeiro - CEASA MA from 2016 to 2017. Using data processing, the analytic approach of action research, described in comparison to an exploratory analysis of the field to meet the guidelines of the national policy on solid waste. The results showed that food waste still lacks proper control and treatment, and generates express environmental and accounting liabilities, given that some of it is are thrown into enclosure, which is difficult for needy families to access, what is not segregated, turns to slurry, damaging the soil and the nearby water table; the remainder of the waste is routed to landfill, sites, which generates transportion costs. Given, this context, it was to concluded that the applicable public policies the state and local management will need to be integrated, these should aim primarily at raising environmental awareness of the importance of waste management, in the purpose of Converting soil degradation and accounting for damage to a sustainable form of, development thereby emphasizing environmental preservation and combating social inequality.
\end{abstract}

Keywords: Environmental awareness; Sustainable development; Environmental liabilities; National waste policy 


\section{Introdution}

Disorderly consumption, hunger, and waste contextualize direct discussions about environmental liabilities. This is mainlay because of a defined public policies in Brazil, especially when the consequences involve accounting costs, environmental impacts, and damage to fundamental rights. The allocation of this situation refers to fragile situations, the lack of awareness and lack sustainable understanding (GONÇALVES, 2006).

In this area, the control of environmental accounts concerning sustainable awareness, appears in the socioeconomic context of government programs, such as the use of a mandatory lexicon, either in official speeches or in indirect speeches about improvement parameteres that initially served, to designate biological and natural processes, from the 18th to 19th centuries; it was used to describe sustainable processes as the basis for human and economic development in the continuation of "natural" approach (DAMBORIARENA, 2001).

Consider in possibilities: reverse logistics through these foods could be used to improve family farming via the creation of compost. The same process could also create food banks and food destined for those who really need it. Moreover, creating partnerships with universities and treating waste are activities that can provide financial benefits; for example, the use of coconut shell can produce grout, and even the combination of garlic and onions can produce an excellent fertilizer. These activities could also enable, the generation of employment and income with the integration of waste pickers on site.

The issue, is that many of these foods, harm the soil and groundwater, and within the management process, millions are spent on the transportation of this wastes to landfill sites. The central supply can act as a socio-environmental link to in what it concerns sustainable and socioeconomic improvement.

In this regard, a discussion was proposed on the instruments of readjustment between the terms of socio-environmental responsibility and the conversion of waste, as a plausible measure for obtaining environmental results and socioeconomic improvements, given the inadequate disposal of solid waste in CEASA MA. The proposal, in the context of this conversion of waste, involves the use of attitudes and values of educational character that according to Law 9.975/1999, are regulated by Decree 4.281/2002: "The social values, knowledge, skills, attitudes and competences focused on the conservation of the environment, intended for the of common use of the people, are essential to the sound quality of life and its sustainability ". This statement can be the basis for socioeconomic improvements and for the growth of environmental awareness.

It is believed that the capacity for awareness and conversion of liabilities are fundamental allies in the issues described by the Waste Convention. For this relationship to be viable, it is necessary to have a comprehensive basis of education integrated into the environmental management process that: "Provides better conditions for the production and, acquisition of knowledge and skills, and, that develops attitudes, aiming at individual and collective participation in the management of the use of environmental resources and in the conception and application of decisions that affect the quality of the physical-natural and sociocultural means in the studied environment" (QUINTAS, J. 2000,p.18). 


\section{Theoretical references}

In this approach, the composition of the theoretical reference is essential to understanding of the concept and the historical basis to understand the food convention, for the benefit of sustainability and the socioeconomic processes. The following topics were evaluated.

\subsection{Accounting and environmental awareness of sustainable development}

In the twentieth century, the notion of accounting linked to environmental awareness for sustainable and socioeconomic improvement was, not based on a well-formed premise. The focus was on capitalist development, and it was described in the inauguration speech of the President of the United States, Harry Truman (ESTEVA, 2000). - This definition of capitalism suggest environmental accounting is one of the most fraught and ideological of concepts, which is corroborated by the powerful intellectual filter of our perceptions of the contemporary world; as such it leads, us to a divergence from a sustainable point of view in an disordered consumption, constituted by economicism and Eurocentrism (VIOLA, 2000).

In this approach, it is understood that economicism as treated by accounting, has a relevant role in the configuration of the dominant images of awareness and development; but there is a wide divergence in that context, especially when weare dealing with the fever of consumerism. It is found in the perceptions of development concerning the economic growth of some countries and the precarious situation of others; yet, with the diffusion of the market economy, the situation has become catastrophic because we encounter famine, rubbish, and misery. In turn, Eurocentrism overloads the discourse of sustainable development in a differentiated way, bringing to the fore Western culture as a universal parameter to measure the relative delay and progress of other peoples of the world.

From that perspective,

\footnotetext{
"To observe in this approach that, this ideology, anchors itself in some fundamental principles of western modern thought: in the unlimited faith of the inexhaustible scientific contributions (in the form of technology and efficient organizations) to the progress of our quality of life with its disordered consumption."(MACHADO, 2012, pp.39-56)
}

However, to be able to enter into this process, an understanding of the "Western cultural package" must be adopted, with the programs that reflect second Viola: "Capitalism, industrialization, advanced technology and representative democracy, but also individualism, secularization and utilitarianism" (VIOLA, 2000. p.16).

This process refers us to a dimension of the notion of development without awareness whose theoretical basis of the first notion is constituted in liberal theory, because its criteria for transformation are aligned to progress, growth, consumerism, environmental impact, distribution and markets. This paradigm is counterposed in relation to treatment pertaining to preservation of the environment; it is sustained, with the desire to consume, and it is understood that, with the crisis of the liberal paradigm, it can observed in the weakening of expectations for a cumulative, unlimited and universal progress, and the difficulty of sustaining developmental speech. Based on the Marxist paradigm, it emerged as a new position, namely, environmental awareness that highlight the use and limits of natural resources; this has made the planet 
evaluate the environmental impacts of disorderly consumption, somitimes even in a transformative manner, and adapt the scale of production to its reality on many occasions.

In this context, the dichotomies of the "alternative to environmental improvement" and "environmental improvement for socioeconomic development enable" a new approach that was reffed to by public policies and social movements as environmental awareness; this new approach directs to the action, especially when we deal with specific hunger issues (BUENO, 2013).

In this field of analysis, sustainability demonstrates its great transformative capacity, and here, reveals the continuation of its reproductive capacity, as well as weakening the disordered cycle of capitalist consumption, its excesses, and its differences. Using this definition, Bhabha suggest the term mimicry, stating that "Mime is one of the most cunning and effective strategies of colonial power and knowledge" (BHABHA, 1998. p.130).

This speech behaves like the concept of development in its negative form and shows us how some actions can cause disruption to our social values and consequently have an impact on our common assets. As an example, consider the explanatory scheme of social groups since the memorable speech of President Harry Truman's inauguration in North America. The development vs. sustainability model is presented from there as a "Su concepto de fair deal" (Escobar, 1996. p. 19), transforming a certainty into social imagery. In other words, developmentalism created, through a colonial discourse, a defined field of thought and action, and consequently brought about a socioeconomic slowdown in some countries, as well as environmental damage, poverty, waste, garbage, and famine.

On this basis, the dissociative principle among famine, waste, and environmental impacts is, to direct us to more timely situations of this mimicry, the exemples of extreme poverty. Here, it is possible to allocate the call of the United Nations Organization (UN 2017) which emphasizes, the \$534 billion invested to circumvent famine in the world; the equivalent sum of $\$ 1.5$ billion is wasted without proper disposal. This causes total divergence from the prospects established by capitalist growth against the foundations for improving social and environmental issues, as the increase in waste is leading us to more punctual issues, or what Demajorovir (2001) would call social and environmental responsibility.

\subsection{National Solid Waste Policy (PNRS)}

In Brazil, one of the guidelines established for understanding socio-environmental responsibility is the national solid waste policy (PNRS). This was well defined by Law $n^{\circ} .12,305$, of August 2, 2010, and intended mainly for the "protection of public health and the environment, when the approach is the classification of waste". As a public policy, its function is to stimulate and encourage a change in production and consumption stand that favor sustainable development; PNRS enables this improvement through the conscious application of reverse logistics (BRAZIL, 2010).

In its formulation, PNRS contains the principles, objectives, instruments and guidelines for integrated and solid waste management, and hazardous waste, to the responsibilities of the waste generators and public authorities, and the applicable economic instruments (BRAZIL,2010). Solid waste generators are considered to be natural or legal persons, in public or private law, which generate solid waste by means of their activities, including consumption (Brazil, 2010). 
Thus the management process instituted through the integrated solid waste administration must be understood as the set of actions aimed at identifying sustainable solutions, being evaluated during the transition, and the guidelines of socioeconomic policy, both environmental and cultural; these operate, under a premise of sustainable development that portrays fundamental rights and shared responsibilities as common to the growth and maintenance of the environment (BRAZIL, 2010).

According to Arruda (2004), the understanding of shared responsibility, dealt with in the guidelines and the principles points out that in article 25 of the said law "The public power, the sector and the collectivity are responsible for the effectiveness of the actions focused on ensuring compliance with the PNRS. Thus exposes Morelli (2009) "Each of the agents is assigned some responsibility, with the business sector (manufacturers, importers, distributors and traders) to fulfill the obligations alson imposed by articles 30 to 33 of the PNRS" $(2009 \text {, p. } 23)^{1}$.

The accountability for sharing the issue of solid waste demonstrates a clear relationship between PNRS and socio-environmental responsibility. In this sense, the confrontation of these socio-environmental problems and the option for a "sustainable development" that is, ecologically balanced, as foreseen in art. 225. The federal constitution is inevitably based on the correction of social inequalities, and the view that the effectiveness of social rights is necessarily connected to favorable environmental conditions (BAUMAN, 2013).

In this way, sustainability can be developed through the proper use of solid waste, with the logistical possibility of using integrated models that, are determinant both of non-generation, which will be shown to involve a major change in the current standard of production (reduction, reuse, and recycling), and of those types of waste that can still serve as raw materials or inputs for the productive processes (BARBIERI,2003)

In this process, we have the Hortifrutigranjeiro supply centers, partners for the various stages of integrating sustainability.

\subsection{Hortifrutigranjeiro Supply Center CEASA MA}

In Brazil, the landmark originating in the CEASAs, was consolidated in mid-1970. However, in many ways, the historical basis of this context in many moments is portrayed by the year 1957, which the search for exemplary models of Hortigranjeiro marketing, was observed in France as an expression model of commercial development. Given this context, it was only in 1972 through Decree 70,502 of the federal government that this model emerged in the national system of supply centers (SINAC). That made commercial control possible through the creation of the strategic development program, which would structure the CEASAS in the country (CUNHA, 2006).

Over a two-year period, guidelines instituted in this program, contextualized, the strategic definition for improvements in socioeconomic development. In this linkage, a differentiated model was generated through this understanding, which consisted of three public front: the Brazilian food company

\footnotetext{
${ }^{1}$ According to (PNRS) in article 3, item XVI, solid residue is: [] material, substance, object or well discarded resulting from human activities in society, whose final destination is proceeding, whether it proposes to proceed or whether it is obliged to proceed, in the solid states or Semissólido, as well as gases contained in receptacles and liquids whose particularities make it unfeasible to launch it in the public sewer system or in water bodies, or require technical or economically unviable solutions in the face of the best technology Available (PNRS, 2012, p. 11).
} 
(COBAL), Brazilian storage company (CIBRAZEM), and the production financing company (CFP). In the organizational process, these types of programs allowed for greater proximity to European models, because they established several commercial cultural projects in the same space, rather than just food, and the process followed the mixed (public and private) model of fiscal management (TOFANELLI et al., 2009).

From these advances it was possible to conceive of the elements required, to create a fundamental bases for the creation of the CEASA, from which measures and improvements; could be generated from a central perspective; these mainly consisted a union between the public and the private sector. The first CEASAS appeared in São Paulo (CEAGESP inaugurated in 1966) and Recife (CAIXETA FILHO, 1995).

The mixed fiscal activity of CEASA, raised the limitations on, commercial improvement, from which emerged a new form of produce food management, constituted by a stable set of commercial companies in the same place (marketing fruit, flowers, non-perishable food, vegetables, fish, etc.). This process today follows the guidelines instituted by the National Supply Company - CONAB, manager in the food distribution process. In Brazil, there are 62 supply centers, managed by CONAB and all follow the market SPOT model. However, one of the weaknesses of the centers is the amount of food waste due often produce in the storage process and the lack of logistical planning (BELIK et al. 2000).

However, in the Capital-Maranhão region the CEASA began in October 1977 with the prospect of better marketing and control for small farmers. The produce cooperative of Maranhão LTDA, has approximately 80 commercially diversified, and 550 contributors; according to CONAB annual production in 2016 was estimated at 116,603,160 $\mathrm{kg}$ of products available for marketing, the equivalent of approximately $\$ 47,423,909.80$. Throughout the state of Maranhão, trade relies solely on this supply center for all the capitals in the region. Overall, the entire area had built only two sheds at the end of 2016 for the disposal of waste.

Given this approach, it is possible to observe more specific waste issues the SPOT, which leads us to the necessary questions concerning the lack of more equitable public policies and their effects in targeting these foods, which could in some way supply the needs of vulnerable and disadvantaged communities (LIMA et al.,2013).

In this process, we have the Hortifrutigranjeiro supply centers, partners for various stages of integrating sustainability.

\section{Methodological procedures}

The methodological structure of this analysis was designed through systematic research activities, which systematically for Cerati and Lazarini (2009) point out provide the essential guidelines for change, and for minimization of socio-environmental conflicts. Given these paraments, Thiollent (2007) states, that this type of research serves to bring the researcher closer to his or her field of study; and this builds parameters, to contain the lack of a transformer understanding. For Vergara (2000), the basis of this interpretative understanding, is in participatory planning, where the most directly compared actions of the field, are transformed through the research, and serve as a means to evaluate the problems and generate suggestions of conventions to address them.

With this approach, it was essential to use the participatory intervention process to evaluate the field, discuss the environment, compare the singularities, and highlight actions for improvements. What 
Barbier (2004) would call youth intervention, where the participatory process allows the study to be carried out more directly and the most plausible results. In this context, three essential steps of the process were undertaken, which emphasized between them 1):-the knowledge and comparison of the positive and negative aspects of the site, and - the volume of materials wasted according to studies of the area and environmental reports, and 2) -knowledge of forms of waste separation, and 3) criteria of the actual waste. Despite the potential for possible conflicts in these steps, they enable understanding of now, to evaluate the sustainable improvements in the field; this approach also addressed the interactivity of the object of study with its scientific basis.

The understanding obtained through this socio-environmental intervention through direct observation, found that actions are better directed, especially when we deal with food waste conventions. According to Collis and Hussey (2005), and Macke (2006), these actions can be evaluated by the preplanning parameter related to conscious reuse; whether from, ignorance, or even from the absence of converted actions that increase the results and the potential for improvement in the field, it is only possible to make the transition through a specifically participatory approach, and this can only be accomplished if data collection is undertaken during in the process.

\subsection{Data Collection}

The time period during which data collection, was conducted began, in July 2016 and ended in August 2017, during the orientation of the scientific research project "Group Environmental Planning" of the University of Ceuma. Where the analysis showed the possibility of elucidating the waste problems with the application of sustainable solutions for minimizing impacts, the following factors were taken into account.

-the place of research site would be chosen for its high volume of food marketing;

-the produce cooperative of Maranhão LTDA, located on Avenida Jerome de Albuquerque, 2961Cohafuma, São Luís-MA, has approximately 80 stalls, and 550 contributors;

-the potential for waste: it;

- is estimated that the equivalent of 36,000 tons of waste organic waste is organic, according to the CONAB National Supply Company, and;

-knowledge of the field;

-nineteen visits to the site were conducted using observation to determine the level of knowledge of employees; improvement actions and the possibilities of transformation; participation of management on the means of implementation and processing of waste, the negative environmental factors generated by waste, and the; the relevant number of needy families on site;

For analysis of the socioeconomic context, the analysis took account of the following factors:

The commercial report dispatched by CONAB for evaluating of accounting liabilities in relation to the environment; and the positioning of the Ceasa institution in the process of sustainable awareness. 


\section{Results and discussion}

The guidelines of the national solid waste policy were considered during the analysis, and it was regarded essential to connect the bibliographic context with the reality of the site. In the first visit, the singularities between the law and the field were identified as shown in Table 1.

Table 1: Singularity between the objective of the law and the field in 2016

\begin{tabular}{|c|c|}
\hline Legislation 12.305/2010 (PNRS) & CEASA MA \\
\hline \multirow{4}{*}{$\begin{array}{l}\text { Art. } 7 \text { The objectives of the national policy of } \\
\text { solid waste II-non-generation, reduction, } \\
\text { reuse, recycling and treatment of solid waste, } \\
\text { as well as the final environmentally } \\
\text { appropriate disposition of the waste. }\end{array}$} & Food display \\
\hline & Inappropriate segregation \\
\hline & Polluting potential \\
\hline & Inappropriate destination \\
\hline
\end{tabular}

This complexity of Table 1, shows how the lack of understanding about the normative guidelines of the 12.305/2010 law, generates a dissociative view between legal guidelines and the field, or what EDEN (2001) and HUXHAM (2001) would call managerial divergence in the process of environmental improvement. Understanding of this approach was identified on the second and third visits, together with the lack of employee knowledge of the site regardung sustainable processes and the transformation of organic waste. According to BRAGA (2008) allowed greater transformation of the studied medium. That is, this lack of knowledge generated the high content of waste, lack of selective collection and a large number of vulnerable persons on the site.

It was also clear that the increase in vulnerable people in the area had a direct link to the increase in waste and famine, which according to FIORILLO (2007), is the result of alternative sources of living for those in extreme poverty. As observed in Figure 1, the result of this ignorance allowed the identification of, several types of waste thrown onto in the exposed terrain, thus damaging the soil and the groundwater in its proximity; this consequently affected the, vulnerable who in searching for food, ended up collecting this waste for family consumption. Figure 1 shows the inadequacy of the final destination.

Figure 1- Waste and vulneable, 2016

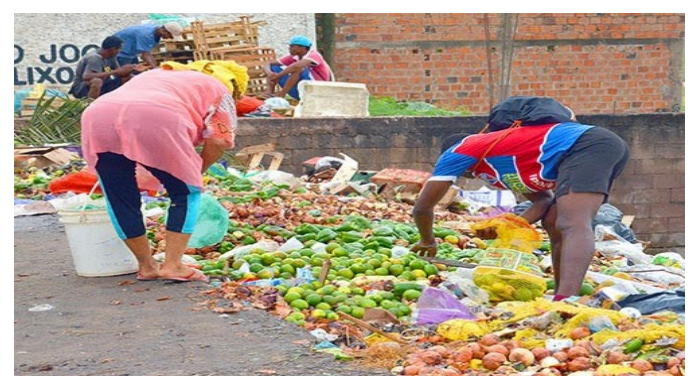

The availability of this waste was still apparent by the end of 2016. Figure 1 clearly, it shows the waste the needs of the vulnerable on the site. After having been verified over several transitions, the local media called for attention to the policy of inclusion, and the fact that many of these foods could serve as a 
basis for, the socio-environmental program of food banks, as constituted within the CEASA. The food bank according to SILVA (2000), is a product of the social and integrative cooperation of some of the country's governments, which enables vulnerable communities to access clean food and the possibility of consuming it.

Through the food bank, it is possible to identify the nutritional value of what can still be retained, or even transformed. However, the mobilization of this act at CEASA MA only occurred in March 2017, through the government's initiative on local media enforcement. In Figure 2 the CEASA attempt is observed in the convention of this waste. After several meetings, educational lectures, and new proposals from the state government, CEASA created a shed covered for reception of these foods.

Figure 2 - The CEASA created a shed covered for reception

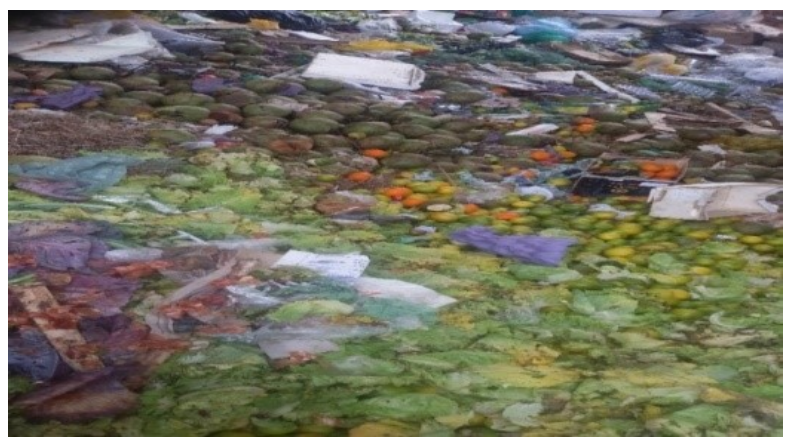

During the fifth to the eleventh visit was possible to identify, the need to review the CEASA's environmental concepts in the CEASA, and to highlighting the urgent need for the state to implement integrated management of solid organic residue so as to constitute the project, became apparent. Secretariat of Infrastructure held some meetings to compose the integrated process of changes, which would assess the efficient treatment of the disposal of solid organic waste in order, to generate benefits from clean food separation. In doing so, they took the first step outlined in the document and structural process of the food bank.

\subsection{Positive Aspects}

After this understanding, the CEASA built a wall inside the shed to separate the waste. Figure 3 shows the positive outcome of this transformation, with CEASA MA's orientation partnership with the government creating a starting point for the separation of food through a specific project created the food bank.

Figure 3 - shed of vegetables and fruits already separated

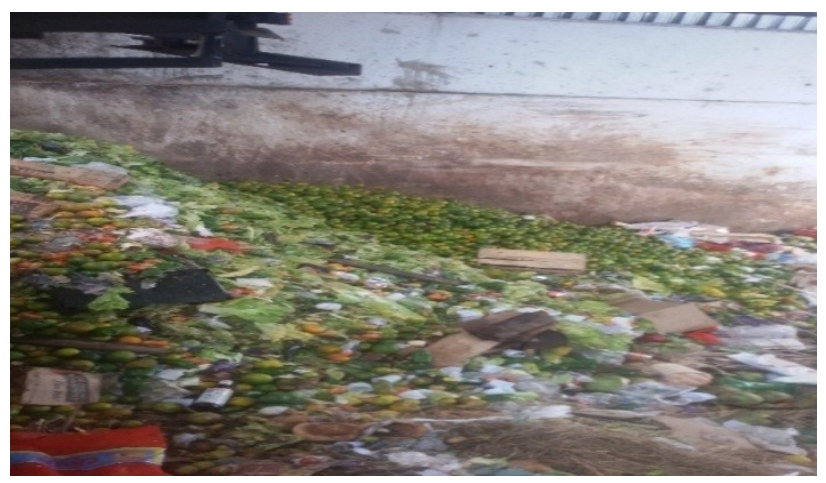


Figure 3 shows the first milestone of change, and the organic recognition of the importance of organic vegetables and fruits that are so often wasted but here are separated; improvements in the process of getting them to their destination, are expected. Figure 4 also depicts the evolution of the separation of waste, the organizational process between solid and organic, which would allow the CEASA at this stage to provide its solid waste to the cooperatives. They would then treat this material in a sustainable and economical way leading to environmental improvements.

Figure 4 - Solid waste shed for cooperative use

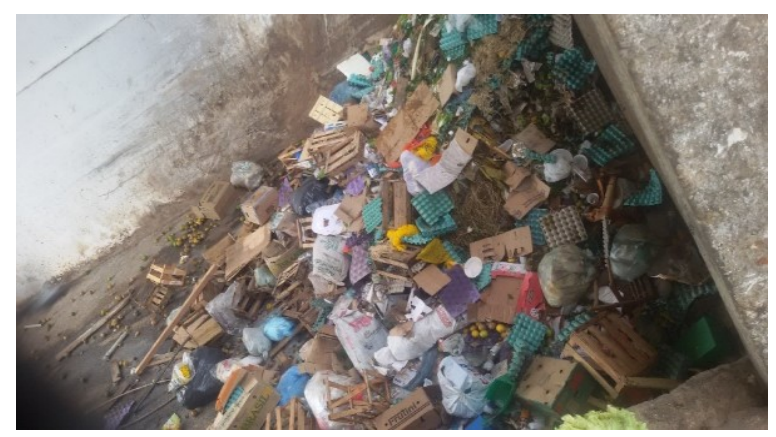

In this process, Figures 3 and 4 reveal the development of sustainability through actions, indicating improvements; these are highlight in Table 2 the summary is of the sustainable actions carried out, and their positive and negative aspects in the process of transition for applicability of general actions in CEASA MA.

Table 2 - Sustainable actions and their negative and positive aspects

\begin{tabular}{l|l|l}
\hline \multicolumn{1}{c|}{ Sustainable actions } & \multicolumn{1}{|c}{$\begin{array}{c}\text { Demerits } \\
\text { Beginning }\end{array}$} & \multicolumn{1}{c}{ Today } \\
\hline Profile & $\begin{array}{l}\text {-Large number of foods: } \pm 36,000 \\
\text { tons wasted }\end{array}$ & $\begin{array}{l}\text {-Separation of solid waste } \\
\text { from organic waste }\end{array}$ \\
\hline Final destination & -Ignorance about final destination & -Food Bank \\
\hline Selective collection & -There was & -Register of vulnerable \\
\hline $\begin{array}{l}\text { Environmental } \\
\text { management }\end{array}$ & $\begin{array}{l}\text {-There is no environmental } \\
\text { certification }\end{array}$ & -Creation of Shed \\
\hline
\end{tabular}

According to JACOBI (2003), environmental education provides greater sustainable understanding; it alson highlights essential solutions for socioeconomic contributions because it "seeks to consider the political, economic, environmental, cultural and social dimensions, with social control under the premise of sustainable development" (art. 3, item XI of the law 12.305/2010). In table 3, we show the volume of food marketed. According to CONAB - National Supply Company, CEASA MA commercialized the volume of food at $116,603,160 \mathrm{~kg}$ of products available for consumption, which amounts an approximate value of $\$ 47,423,909.80$. When we perceive the wasted volume of $\pm 36,000$ tons, we immediately understand that there is a considerable liability in local revenue. By 2017, the volume was $155,192,570 \mathrm{~kg}$. However, if we into account the possibility of conscious reuse the injury will become a great benefit to the three stakeholders: the environment, CEASA and needy families (FREITAS,2012). 
Table 3-Volume marketed in 2016

\begin{tabular}{c|c|c|c|c}
\hline \multicolumn{2}{c|}{} & \multicolumn{3}{|c}{ HORTIFRUTIGRANJEIROS } \\
\hline $\begin{array}{c}\text { Wholesale } \\
\text { Warehouse }\end{array}$ & Weight (kg) 2016 & $\begin{array}{c}\text { \%change in } \\
\text { relation to } \\
2015\end{array}$ & Value(R\$) 2016 & $\begin{array}{c}\text { \%change in } \\
\text { relation to } \\
2015\end{array}$ \\
\hline $\begin{array}{c}\text { CEASA-BA } \\
\text { SALVADOR }\end{array}$ & $463,786.056$ & $-12,28 \%$ & $1,089.987,26$ & $6,44 \%$ \\
\hline $\begin{array}{c}\text { CEASA -BA } \\
\text { PAULO AFONSO }\end{array}$ & $7,151.789$ & $-30,90 \%$ & $20,811.811,45$ & $-24,63 \%$ \\
\hline $\begin{array}{c}\text { CEASA-CE - } \\
\text { FORTALEZA }\end{array}$ & $510,087.470$ & $-4,53 \%$ & $1,371.506 .940,00$ & $11,18 \%$ \\
\hline $\begin{array}{c}\text { CEASA-CE- } \\
\text { TIANGUÁ }\end{array}$ & $77,241.400$ & $2,36 \%$ & $121,814.490,00$ & $20,95 \%$ \\
\hline $\begin{array}{c}\text { CEASA-CE } \\
\text { CARIRI }\end{array}$ & $51,514.130$ & $5,31 \%$ & $80,634.780,00$ & $7,00 \%$ \\
\hline $\begin{array}{c}\text { CEASA-SÃO } \\
\text { LUÍS }\end{array}$ & $116,603.160$ & $-11,13 \%$ & $47,423.909,80$ & $-36 \%$ \\
\hline $\begin{array}{c}\text { CEASA PB } \\
\text { CAMPINA } \\
\text { GRANDE }\end{array}$ & $151,920.674$ & $3.57 \%$ & $306,234.563,55$ & $-3,39 \%$ \\
\hline $\begin{array}{c}\text { CEASA - PB } \\
\text { JOAO PESSOA }\end{array}$ & $117,718.429$ & $-2,48 \%$ & $230,766.015$ & $8,87 \%$ \\
\hline $\begin{array}{c}\text { CEASA-PB } \\
\text { PATOS }\end{array}$ & $40,241.031$ & $-6.06 \%$ & $70,318.841,53$ & $15,39 \%$ \\
\hline $\begin{array}{c}\text { CEASA-PE } \\
\text { RECIFE }\end{array}$ & $649,162.000$ & $-2,04 \%$ & $1,631.450 .000,00$ & $13,84 \%$ \\
\hline $\begin{array}{c}\text { CEASA-PE } \\
\text { CARUARU }\end{array}$ & $23,000.000$ & $-9.09 \%$ & $40,000.000,00$ & $-9,09 \%$ \\
\hline $\begin{array}{c}\text { SUBTOTAL } \\
\text { NORDESTE }\end{array}$ & $2,208.426 .139$ & $-5,10 \%$ & $3,874.627 .428,89$ & $10,54 \%$ \\
\hline
\end{tabular}

If we compare the data, the CEASA MA is well below in its sales volume of $-11.13 \%$, compared to the CEASAS of Recife (13.84\%), ducks (13.84\%) and João Pessoa (8.87\%); this allows us to see that, what was not marketed was wasted. For Monteiro (2001), the waste of organic waste is a socioenvironmental factor, pollution generator, source of harm to public coffers in therms of liabilities, and generator of hunger; in many cases, the singularity of this process draws attention to factors of mobilization where environmental awareness occurs.

According to GUIMARÃES (1995), the process of environmental awareness is fundamental, because it is close to the operational facts: in the case of CEASA what is not marketed, and not obtained by needy families, goes to the landfill. Thus, on the second to ninth visits, it was observed that CEASA on behalf of the government, came to pay more attention to its actions concerning waste throung its involvement in educational lectures, these consisted of, meetings with the governmental actors supported by managers and lectures on socio-environmental awareness involving the participatory membership of the needy community.

All of these actions had a single purpose, to show the improvements made through environmental education. According to BARBIERI (2003), environmental education is the basis for improving the 
educational process. Through this understanding it is possible to change habits that are destructive to the environment, and in this process, it is possible to say that not all garbage is rubbish, and everything in the environment can be transformed.

\section{Final considerations}

Of the material at Ceasa, $64 \%$ is organic residue; in the meetings that occurred during the research period it was noticeable that few people were knowledgeable about the process of reusing waste and its differentiated types of transformation. The solution is the food bank. In this context, we can conclude that CEASA has been seeking strategies to transform its environmental impacts. Using these strategies, much of the food that was wasted, is now treated through rational use.

The food bank program is a reality; however, at the end of this research the had not achieved its effectiveness, because one of the primary errors of the process is exposure, few know about this program or have access to the modes of use that are being disseminated.

During a participant action sessions, it was often suggested to partners with small and medium agricultural products that, composting waste products that would greatly contribute to the generation of vegetable gardens and the creation of more productive organic soil, and consequently to a reduction in the cost of returning vegetables. Moreover, it was important, to enable at partnership with the universities of the capital that could elaborate various educational projects, sucks as, for example, the transformation of coconut shells to grout, or treatment of organic matter to transform it to biogas.

To realizing the difference that these kinds of sustainable action would bring to CEASA MA would mean no longer throwing away 36,000 tons of food but contributing to the improvement of life and generation of employment and income of many communities in the capital and municipalities of Maranhão.

\section{Acknowledgments}

The authors would like to thank CEUMA university.

\section{References}

ABNT, Associação Brasileira de Normas Técnicas. NBR 10004. Resíduos sólidos - Classificação. 2004.

BARBIER, RA. A Pesquisa-Ação. Tradução de Lucie Didio. Brasília: Líber Livro Editora, 2004.

BARBIERI, JC, Gestão Ambiental Empresarial: conceitos, modelos e instrumentos. 2nd. Saraiva, São Paulo, SP, 2008.

BARBIERI, JC. Desenvolvimento e Meio Ambiente: as estratégias de mudanças da Agenda 21. Rio de Janeiro: Vozes, 2003

BAUMAN, Z. Danos colaterais: desigualdades sociais numa era global. Trad.:Carlos Alberto Medeiros. Rio de Janeiro: Zahar, 2013

BELIK, W.; SILVA,JC, TAKAGI, M. Políticas de combate à fome no Brasil. São Paulo Perspec., São Paulo, v. 15, n. 4, p. 119-129, out./dez. 2001. 
BHABHA, H., (1998, p.130). O local da cultura. Belo Horizonte: UFMG.

BRAGA M. C \& DIAS C. N.; Gestão de Resíduos Sólidos Urbano. Volume I. Curitiba, 2008.

BRASIL. Constituição (1988). Constituição da República Federativa do Brasil. Organização de Alexandre de Moraes. 16.ed. São Paulo: Atlas, 2000.

BRASIL. Lei n. ${ }^{\circ} 12.305$ de 02 de agosto de 2010. Política Nacional de Resíduo Sólido. Disponível em: http:// www.planalto.gov.br Acesso em: 10 jun. 2018.

BRASIL. Ministério do Meio Ambiente - MMA. Conselho nacional do meio ambiente - CONAMA. Dispõe sobre critérios básicos e diretrizes gerais para a avaliação de impacto ambiental. Resolução no 1, de 23 de janeiro de 1986. Lex: Resoluções do CONAMA: resoluções vigentes publicadas entre julho de 1984 e maio de 2006. Brasília: CONAMA, 2006a. p. 636-639.

BRASIL. Portaria, Agência Nacional de Vigilância Sanitária - Portaria 326/97 de 30 de julho de 1997. Available from: http://www.anvisa.gov.br Acesso em 10 de jun. 2018.

BRASIL. Resolução, Conselho Nacional do Meio Ambiente - Resolução CONAMA 001/86 de 23 de Janeiro de 1986. Available from: http://www.mma.gov.br Acesso em 08 jun. 2018.

BUENO, C. Consumo de alimentos: Alimentar uma população crescente é um dos grandes desafios da atualidade. Reportagem UNIVESP,2013. Acesso em 24 ago. 2018.

CAIXETA FILHO, J. V. A modelagem de perdas em problemas de transporte. Revista Teoria e Evidência Econômica, São Paulo, n. 6, p. 49-62, nov.1995.

CERATI, TM e LAZARINI, Rosmari AM. A pesquisa-ação em educação ambiental: uma experiência no entorno de uma unidade de conservação urbana. Ciênc. educ. (Bauru). 2009, vol.15, n.2, pp.383-392.

COLLIS, J.; HUSSEY, R. Pesquisa em Administração. 2. ed. São Paulo: Bookman, 2005.

CONAB. Companhia Nacional de abastecimento. Diagnóstico dos mercados atacadistas de hortigranjeiros. Brasília, DF: CONAB, 2016. Disponível em http://www.ceasa.gov.br/dados/publicacao/pub47.pdf. Acesso em: 16/08/2018.

CUNHA, Altivo Roberto Andrade de Almeida. "Dimensões estratégicas e dilemas das Centrais de Abastecimento no Brasil.” Revista de Política Agrícola 15.4 (2006): 37-46.

DAMBORIARENA, E. Certificação e rotulagem na cadeia dos hortigranjeiros no estado do Rio Grande do Sul: Um estudo de caso - CEASA/RS. 2001. 84 f. Dissertação (Mestrado em Administração) - Escola de Administração, Universidade Federal do Rio Grande do Sul, Porto Alegre, 2001.

DEMAJOROVIC, J. Sociedade de risco e responsabilidade socioambiental: perspectivas para a educação corporativa. Senac, 2001.

DIAS, S.M.F. Avaliação de projetos de educação ambiental voltados para o gerenciamento de resíduos urbanos.2003, 342p.Tese(Doutorado em Saúde Pública-Faculdade de Saúde Pública da USP).São Paulo, 2003.

EDEN,C.;HUXHAM,C. Pesquisa-ação no estudo das organizações. Handbook de estudos organizacionais: reflexões e novas direções.V.2. São Paulo: Atlas, 2001.

ESCOBAR, A. La Invención del Tercero Mundo: construcción y desconstrución del desarrollo. Bogotá: Editorial Norma, 1996.p.19

ESTEVA, G. Desenvolvimento. In: SACHS, Wolfgang (editor). Dicionário do desenvolvimento: guia para o conhecimento como poder. Trad. Vera Lúcia M JOSCELYNE, Susana de GYALOKAY e Jaime E. CLASEN. Petrópolis, RJ: Vozes, 2000. p. 59-83. 
FIORILLO, CP. Curso de direito ambiental brasileiro. 8. ed. São Paulo: Saraiva, 2007.

FREITAS, J. Sustentabilidade: direito ao futuro. 2. ed. Belo Horizonte: Fórum, 2012.

GONÇALVES, CC. Direitos fundamentais sociais: releitura de uma constituição dirigente. Curitiba: Juruá, 2006.

GUIMARÃES, M. A dimensão ambiental na educação. 6.ed. Campinas: papiros, 1995(Coleção Magistério: formação e trabalho pedagógico)

JACOBI, P. Educação, ambiental, cidadania e sustentabilidade. Cadernos de Pesquisa, n.118, p.189-205, 2003.

LIMA, J.S; AMARAL, R.F.; BRITO, A.V.C.; LIMA, P.V.P.S; MAYORGA, R.D. Caracterização dos comerciantes da CEASA - CE. Sociedade e Desenvolvimento Rural online, v. 7, n.4, p.22-36, nov.2013

MACHADO, PL. Princípios da política nacional de resíduos sólidos. In: JARDIM, Arnaldo et al (Org). Política nacional, gestão e gerenciamento de resíduos sólidos. São Paulo: Manole, 2012. p. 39 - 56.

MACKE, J. A pesquisa ação como estratégia de pesquisa qualitativa. São Paulo: Saraiva, 2006

MACKE, J. Ministério do Meio Ambiente-MMA. Conselho Nacional do Meio Ambiente-CONAMA. Licenciamento ambiental de sistemas de disposição final dos resíduos sólidos urbanos gerados em municípios de pequeno porte. Resolução no. 308, de 21/03/2002. Lex: Resoluções do CONAMA: resoluções vigentes publicadas entre julho de 1984.

MACKE, J. Ministério do Planejamento, Orçamento e Gestão. Instituto Brasileiro de Geografia e Estatística - IBGE. Pesquisa nacional de saneamento básico 2000 - PNSB. Departamento de População e Indicadores Sociais. Rio de Janeiro, 2002.2006. Brasília: CONAMA, 2006b. p. 725-727.

MONTEIRO, J.M.P. Manual de Gerenciamento integrado de resíduos sólidos. Rio de Janeiro. IBAM,2001. Available from: http://www.res.com.br/cartilha4/manual.pdfAcesso em: 14.fev.2018

MORELLI, Márcio Raymundo e RIBEIRO, Daniel Verás. Resíduos sólidos:poluição por resíduos sólidos domésticos. São Paulo: Método, 2004. problema ou oportunidade? Rio de Janeiro: Interciência, 2009.

QUINTAS, JS.(org) - Pensando e praticando a Educação Ambiental na Gestão do meio ambiente. IBAMA. Brasília. 2000 .

SILVA.J.A.Tópicos da Tecnologia dos alimentos.Livraria Varela.São Paulo, 2000.

THIOLLENT, M. Metodologia da Pesquisa Ação.15a .ed.São Paulo: Cortez, 2007.

TOFANELLI, M.; FERNANDES, M. S.; MARTINS FB.; CARRIJO, N. S. Avaliação das perdas de frutas e verduras no mercado varejista de Mineiros-GO: em estudo de caso. Revista Scientia Agraria, v. 10, n. 4, p. 331-336, jul./ ago. 2009.

Um bilhão de pessoas passa fome, enquanto a comida é jogada no lixo Available from: http://www.mma.gov.br/ informma/item/9734-um-bilh\%C3\%A3o-de-pessoas-passa-fome,-enquanto-a-comida-\%C3\%A9-jogada-no-lixo. Acesso Em 14.fev.2018

VERGARA, SC. Projetos e relatórios de pesquisa em administração. 3.ed. Rio de Janeiro: Atlas, 2000.

VIOLA, A. La crisis del desarrollismo y el surgimiento de la antropología del desarrollo. In: Viola, Andreu (Comp.). Antropología del dasarrollo: Teorías y estudios etnográficos en América Latina. Barcelona, Piados, 2000. pag. 9-64. 